\title{
Renal Membrane Transport Proteins and the Transporter Genes
}

\section{Sivakumar J T Gowder*}

Qassim University, College of Applied Medical Sciences, Buraidah, Kingdom of Saudi Arabia

\section{Kidney}

In humans, the kidneys are a pair of bean-shaped organs about $10 \mathrm{~cm}$ long and located on either side of the vertebral column. The kidneys constitute for less than $1 \%$ of the weight of the human body, but they receive about $20 \%$ of blood pumped with each heartbeat. The renal artery transports blood to be filtered to the kidneys, and the renal vein carries filtered blood away from the kidneys. Urine, the waste fluid formed within the kidney, exits the organ through a duct called the ureter. The kidney is an organ of excretion, transport and metabolism. It is a complicated organ, comprising various cell types and having a neatly designed three dimensional organization [1]. Due to structural complexity, the intact kidney is difficult to employ for adequate study of many biochemical, pharmacological and physiological processes. Primary cultures of proximal tubule cells have been considered as an appropriate model for the study of proximal tubule cell function or renal intact function [2].

\section{Membrane Transport}

Transporters are membrane proteins present in all living beings. These proteins regulate nutrients, ions, environmental toxins, and other xenobiotics. Transporters are located in intestinal, renal, and hepatic epithelia. Their function involves absorption and elimination of endogenous substances and xenobiotics $[3,4]$. The epithelial layer of the renal tubules alters the volume and composition of filtrate by means of reabsorption and secretion. The surface of the epithelium is organized in such a way that the leakage of salt and water back into the tubule can be minimized. The prominent function of the epithelial layer is to handle ion, solute, and water homeostasis. Renal tubular reabsorption is due to the receptor-mediated endocytic pathway. Epithelial cells are polarized and possess membrane transport proteins [5]. Transporter expression can be regulated due to induction or downregulation of transporter mRNAs. In this editorial, recent research on the renal membrane transporters and their regulation has been discussed with reference to available Pubmed sources.

\section{Genes}

\section{TCN1}

This gene encodes vitamin B12-binding protein family. The transcobalamin-vitamin B (12) complex transport vitamin B12 from plasma and into the tissues. This complex may have high-affinity ligand for the endocytic receptor, megalin that is expressed in the proximal tubule [6]

\section{KCND3}

Voltage-gated potassium (Kv) channels are complicated channels with reference to their structural and functional point of view. Angiotensin receptor forms a complex with potassium channel alphasubunit $\mathrm{Kv} 4.3$ and regulates its intracellular distribution and gating properties [7]. Dihydropyridine $\mathrm{Ca}+$ channel antagonists / agonists may block Kv4.2, Kv4.3 and Kv1.4 K+ channels expressed in HEK293 cells [8].

\section{AQP2}

This gene regulates a water channel protein and it belongs to aquaporin family. Studies show that high sodium diet can increase angiotensin-II and thereby downregulates AQP2 expression. In this way, high sodium diet favors urinary sodium concentration [9]. AQP2 has a role in hereditary and acquired diseases affecting urineconcentrating mechanisms [10]. AQP2 regulates antidiuretic action of arginine vasopressin (AVP). The urinary excretion of this protein is considered to be an index of AVP signaling activity in the renal system. Aquaporins are also considered as markers for chronic renal allograft dysfunction [11].

\section{AQP4}

This gene encodes a member of the aquaporin family of intrinsic membrane proteins. These proteins function as water-selective channels in the plasma membrane. Aquaporin-4 (AQP4) is homologous proteins noticed in the basolateral plasma membrane of the kidney collecting duct, and they mediate the exit pathway for apically reabsorbed water [12]. Renal aquaporins (AQP1-4) concentration is downregulated and is in proportion to the degree of hydronephrosis graded by ultrasound in pediatric congenital hydronephrosis $(\mathrm{CH})$ [13]. The upregulation of AQP4 is directly proportional to the onset and maintenance of saltsensitive hypertension [14]. Vasopressin is involved in the regulation of AQP4 [15].

\section{SLC1A6}

It encodes high affinity glutamate and neutral amino acid transporters. These glutamate receptors are sensitive to dietary regulation [16]. They also function as anion channels [17]. Glutamate upregulates the open probability of the anion pore associated with glutamate transporters [18].

\section{SLC12A5}

$\mathrm{K}-\mathrm{Cl}$ cotransporters are proteins and are involved in the maintenance of intracellular chloride concentrations. The electroneutral cationchloride-coupled cotransporter gene family (SLC12) was identified initially in fish and then in mammals. This nine-member gene family involves two major branches, one including two bumetanide-sensitive $\mathrm{Na}(+)-\mathrm{K}(+)-2 \mathrm{Cl}(-)$ cotransporters and the thiazide-sensitive $\mathrm{Na}$ $(+)$ : $\mathrm{Cl}(-)$ cotransporter. Two of the genes in this branch (SLC12A1 and SLC12A3), exhibit kidney-specific expression and function in renal salt reabsorption. The third gene (SLC12A2) of this family is expressed ubiquitously and plays a key role in epithelial salt secretion and cell volume regulation. The second branch constitutes four genes (SLC12A4- 7) regulate electroneutral $\mathrm{K}(+)-\mathrm{Cl}(-)$ cotransporters [19]. $\mathrm{K}(+)-\mathrm{Cl}(-)$ cotransporters (KCCs) play a fundamental role in epithelial cell function [20]. The $\mathrm{Na}(+)-\mathrm{K}(+)-\mathrm{Cl}(-)$ cotransporters (NKCCs), which belong to the cation- $\mathrm{Cl}(-)$ cotransporter (CCC) family, are able to translocate $\mathrm{NH} 4(+)$ across cell membranes [21].

*Corresponding author: Sivakumar J T Gowder, Qassim University, College of Applied Medical Sciences, P.Box-6800, Buraidah -51452, Kingdom of Saudi Arabia, Tel: +966566873969; Fax: +96663802268; E-mail: sivakumargowder@yahoo.comb

Received January 26, 2013; Accepted January 27, 2013; Published February 03, 2014

Citation: Gowder SJT (2014) Renal Membrane Transport Proteins and the Transporter Genes. Gene Technology 3: e109. doi: 10.4172/2329-6682.1000e109

Copyright: ( 2014 Gowder SJT. This is an open-access article distributed under the terms of the Creative Commons Attribution License, which permits unrestricted use, distribution, and reproduction in any medium, provided the original author and source are credited. 


\section{TRPC1}

The protein encoded by this gene, Transient Receptor Potential Canonical 1 (TRPC1) is a membrane protein that is permeable to calcium and other cations. Higher concentration of glucose increased the expression of TRPC6 and TRPC6-dependent $\mathrm{Ca}(2+)$ influx [22]. TRPC1 gene polymorphisms are associated with type 2 diabetes and diabetic nephropathy in Han Chinese population [23]. TRPC1 channels are associated to mechanosignaling during cell migration [24]. TRPC1 is regulated during the cell cycle progression and is involved in storedepletion-operated $\mathrm{Ca}(2+)$ entry (SOCE), regulatory volume decrease (RVD), and cell proliferation [25].

\section{CLC3}

This gene regulates a member of the voltage-gated chloride channel (ClC) family. The encoded protein is noticed in all cell types and is present in plasma membranes and in intracellular vesicles. ClC-3 channel/antiporter regulates nuclear factor (NF)- $\kappa B$ activation [26]. ClC-3 has nucleocytoplasmic shuttling dynamics and regulates the cell cycle in cancer cells [27]. CIC-3 plays a role in wound closure in Xenopus embryos [28]. ClC-3 Cl (-) channel involved in cell volume regulation and cell cycle [29]. Diabetes results in the alteration in the expression of ClC-3 channels. These changes result in the impaired kidney functions observed in diabetes [30].

\section{References}

1. Yokoo T, Ohashi T, Shen JS, Sakurai K, Miyazaki Y, et al. (2005) Human mesenchymal stem cells in rodent whole-embryo culture are reprogrammed to contribute to kidney tissues. Proc Natl Acad Sci U S A 102: 3296-3300.

2. Gowder SJT, McMartin KE (2010) Development of a primary culture system of rat kidney proximal tubule cells for transport and toxicity studies. J Epithelial Biol Pharmacol 3: 15-19.

3. Dresser MJ, Leabman MK, Giacomini KM (2001) Transporters involved in the elimination of drugs in the kidney: organic anion transporters and organic cation transporters. J Pharm Sci 90: 397-421.

4. Reuss $L$ (2000) Basic mechanisms of ion transport. In, The Kidney Physiology and Pathophysiology. (Seldin D, Giebisch G, eds.) Lippincott Williams \& Wilkins, Baltimore, 85-106.

5. Hamilton KL, Devor DC (2012) Basolateral membrane $\mathrm{K}+$ channels in renal epithelial cells. Am J Physiol Renal Physiol 302: F1069-1081.

6. Nielsen R, Sørensen BS, Birn H, Christensen El, Nexø E (2001) Transcellular transport of vitamin $\mathrm{B}(12)$ in LLC-PK1 renal proximal tubule cells. J Am Soc Nephrol 12: 1099-1106.

7. Doronin SV, Potapova IA, Lu Z, Cohen IS (2004) Angiotensin receptor type 1 forms a complex with the transient outward potassium channel Kv4.3 and regulates its gating properties and intracellular localization. J Biol Chem 279 : 48231-48237.

8. Hatano N, Ohya S, Muraki K, Giles W, Imaizumi Y (2003) Dihydropyridine Ca2+ channel antagonists and agonists block Kv4.2, Kv4.3 and Kv1.4 K+ channels expressed in HEK293 cells. Br J Pharmacol 139: 533-544.

9. Della Penna SL, Cao G, Fellet A, Balaszczuk AM, Zotta E, et al. (2012) Saltinduced downregulation of renal aquaporins is prevented by losartan. Regul Pept 177: 85-91

10. Tamma G, Procino G, Svelto M, Valenti G (2012) Cell culture models and animal models for studying the patho-physiological role of renal aquaporins. Cell Mol Life Sci 69: 1931-1946.

11. Ho KM, Li AZ, Yiu MK, Lee KC, Lui VC, et al. (2005) Altered expression of aquaporin-2 in human explants with chronic renal allograft dysfunction. BJU Int 95: 1104-1108.

12. Arnspang EC, Sundbye S, Nelson WJ, Nejsum LN (2013) Aquaporin-3 and aquaporin-4 are sorted differently and separately in the trans-Golgi network. PLoS One 8: e73977.

13. Li ZZ, Xing L, Zhao ZZ, Li JS, Xue R, et al. (2012) Decrease of renal aquaporins $1-4$ is associated with renal function impairment in pediatric congenital hydronephrosis. World J Pediatr 8: 335-341.
14. Procino G, Romano F, Torielli L, Ferrari P, Bianchi G, et al. (2011) Altered expression of renal aquaporins and Ît-adducin polymorphisms may contribute to the establishment of salt-sensitive hypertension. Am J Hypertens 24: 822828.

15. Van Hoek AN, Bouley R, Lu Y, Silberstein C, Brown D, et al. (2009) Vasopressininduced differential stimulation of AQP4 splice variants regulates the inmembrane assembly of orthogonal arrays. Am J Physiol Renal Physiol 296: F1396-1404.

16. Howell JA, Matthews AD, Swanson KC, Harmon DL, Matthews JC (2001) Molecular identification of high-affinity glutamate transporters in sheep and cattle forestomach, intestine, liver, kidney, and pancreas. J Anim Sci 79: 13291336.

17. Machtens JP, Kovermann P, Fahlke C (2011) Substrate-dependent gating of anion channels associated with excitatory amino acid transporter 4. J Biol Chem 286: 23780-23788

18. Melzer N, Biela A, Fahlke C (2003) Glutamate modifies ion conduction and voltage-dependent gating of excitatory amino acid transporter-associated anion channels. J Biol Chem 278: 50112-50119.

19. Hebert SC, Mount DB, Gamba G (2004) Molecular physiology of cation-coupled Cl- cotransport: the SLC12 family. Pflugers Arch 447: 580-593.

20. Wei WC, Akerman CJ, Newey SE, Pan J, Clinch NW, et al. (2011) The potassium-chloride cotransporter 2 promotes cervical cancer cell migration and invasion by an ion transport-independent mechanism. J Physiol 589: 5349 5359

21. Bergeron MJ, Gagnon E, Wallendorff B, Lapointe JY, Isenring $P$ (2003) Ammonium transport and $\mathrm{pH}$ regulation by $\mathrm{K}(+)-\mathrm{Cl}(-)$ cotransporters. Am J Physiol Renal Physiol 285: F68-78.

22. Yang $H$, Zhao B, Liao C, Zhang R, Meng K, et al. (2013) High glucose-induced apoptosis in cultured podocytes involves TRPC6-dependent calcium entry via the RhoA/ROCK pathway. Biochem Biophys Res Commun 434: 394-400.

23. Chen K, Jin X, Li Q, Wang W, Wang Y, et al. (2013) Association of TRPC1 gene polymorphisms with type 2 diabetes and diabetic nephropathy in Han Chinese population. Endocr Res 38: 59-68.

24. Fabian A, Bertrand J, Lindemann O, Pap T, Schwab A (2012) Transien receptor potential canonical channel 1 impacts on mechanosignaling during cell migration. Pflugers Arch 464: 623-630.

25. Madsen CP, Klausen TK, Fabian A, Hansen BJ, Pedersen SF, et al. (2012) On the role of TRPC1 in control of Ca2+ influx, cell volume, and cell cycle. Am J Physiol Cell Physiol 303: C625-634.

26. Yang H, Huang LY, Zeng DY, Huang EW, Liang SJ, et al. (2012) Decrease of intracellular chloride concentration promotes endothelial cell inflammation by activating nuclear factor-î̃ B pathway. Hypertension 60: 1287-1293.

27. Mao J, Li X, Chen W, Xu B, Zhang H, et al. (2012) Cell cycle-dependent subcellular distribution of CIC-3 in HeLa cells. Histochem Cell Biol 137: 763776 .

28. Fuchigami T, Matsuzaki T, Ihara S (2011) Possible roles of $\mathrm{ENaC}$ and $\mathrm{Cl}(-)$ channel in wound closure in Xenopus laevis embryos. Zoolog Sci 28: 703-711.

29. Qian Y, Du YH, Tang YB, Lv XF, Liu J, et al. (2011) CIC-3 chloride channel prevents apoptosis induced by hydrogen peroxide in basilar artery smooth muscle cells through mitochondria dependent pathway. Apoptosis 16: 468-477.

30. Fu J, Fu J, Gao B, Wang L, Zhang N, et al. (2010) Expression patterns of CIC-3 mRNA and protein in aortic smooth muscle, kidney and brain in diabetic rats. Clin Invest Med 33: E146-154. 